\title{
Expression of the nociceptin/orphanin FQ receptor in the intestinal mucosa of IBS patients
}

\author{
LU LI, LEI DONG and SHENHAO WANG
}

\begin{abstract}
Department of Gastroenterology, The Second Affiliated Hospital, Medical School of Xi'an Jiaotong University, Xi'an, Shaanxi 710004, P.R. China
\end{abstract}

Received February 17, 2013; Accepted May 17, 2013

DOI: $10.3892 /$ etm.2013.1186

\begin{abstract}
Nociceptin/orphanin FQ (N/OFQ) and the N/OFQ peptide (NOP) receptor play important roles in regulating gastrointestinal function. To assess whether the NOP receptor is implicated in the etiopathogenesis of irritable bowel syndrome (IBS), we measured the levels of NOP receptor mRNA and protein in the jejunal and colonic tissues of healthy subjects and patients with diarrhea-predominant IBS (D-IBS) and constipation-predominant IBS (C-IBS). Mucosal biopsies were obtained from the jejunum and colon of patients diagnosed with D-IBS and C-IBS by the Rome III criteria and from healthy control subjects. The expression of NOP receptor mRNA was measured quantitatively using quantitative PCR (qPCR) and NOP protein expression was assayed immunohistochemically using a rabbit monoclonal antibody to OFQ. NOP receptor mRNA was detected in the jejunum and colon of healthy subjects and was more highly expressed in the jejunum than in the colon. Expression was lower in the jejunum and colon of patients with D-IBS; however, it was similar in patients with C-IBS and healthy subjects. The numbers of OFQ-positive cells in the jejunum and colon were similar among the three groups. The NOP receptor may be involved in the regulation of intestinal movement in healthy individuals. Its involvement in the pathophysiology of IBS may depend on whether the IBS is constipation- or diarrhea-predominant.
\end{abstract}

\section{Introduction}

Irritable bowel syndrome (IBS) is a chronic widespread disease responsible for $40 \%$ of outpatient consultations and it affects $15 \%$ of adults in western countries $(1,2)$. IBS often has severe consequences, with patients often having

Correspondence to: Professor Lu Li, Department of Gastroenterology, The Second Affiliated Hospital, Medical School of Xi'an Jiaotong University, 30 Huangchengxi Road, Xi'an, Shaanxi 710004, P.R. China

E-mail: cnluli@yeah.net

Key words: nociceptin/orphanin FQ, irritable bowel syndrome, intestinal mucosa impaired health-related quality of life (3-8). IBS is subcategorized into three types: constipation-predominant (C-IBS), diarrhea-predominant (D-IBS) and alternating diarrhea and constipation.

The pathophysiology of IBS may involve alterations in central processing, abnormal gastrointestinal motility and visceral hypersensitivity, and the interactions of these factors are possibly associated with the development of IBS symptoms. For example, the majority of patients with IBS have a lower pain threshold to colonic distension compared with that of healthy subjects (9).

Nociceptin/orphanin FQ (N/OFQ) and the N/OFQ peptide (NOP) receptor have been shown to be involved in the induction of vasodilation and the regulation of reward and motivation pathways related to substance abuse, with the NOP receptor being a candidate target for the treatment of obesity (10-12). N/OFQ and the NOP receptor are present in the central nervous system (CNS) and in the periphery, playing important roles in the modulation of gastrointestinal function and pain (13). To assess whether the NOP receptor is involved in the pathogeneses of IBS, we measured the levels of NOP receptor mRNA and protein in the jejunal and colonic tissues of healthy subjects and of patients with D-IBS and C-IBS.

\section{Subjects and methods}

Subjects. A total of 50 IBS patients who underwent endoscopic polypectomy were divided into the D-IBS group (27 cases) and the C-IBS group (23 cases) following diagnosis according to the Rome III criteria (14). Twenty healthy volunteers were selected as the control group. Subjects were excluded if they were $<18$ or $>80$ years of age, had a history of abdominal surgery, were unable to undergo enteroscopy under general anesthesia or colonoscopy, or had impaired blood coagulation function, including a platelet count $<50 \times 10^{9} / \mathrm{ml}$ or a bleeding time $>14$ min.

All subjects were informed about the purpose and methodology of the study and all provided written informed consent. The study protocol was approved by the ethics committee of Xi'an Jiaotong University (Xi'an, China).

Specimens. Jejunal tissue biopsy specimens were obtained during double-balloon push enteroscopy and colon specimens were obtained during colonoscopy. Four specimens of jejunal 

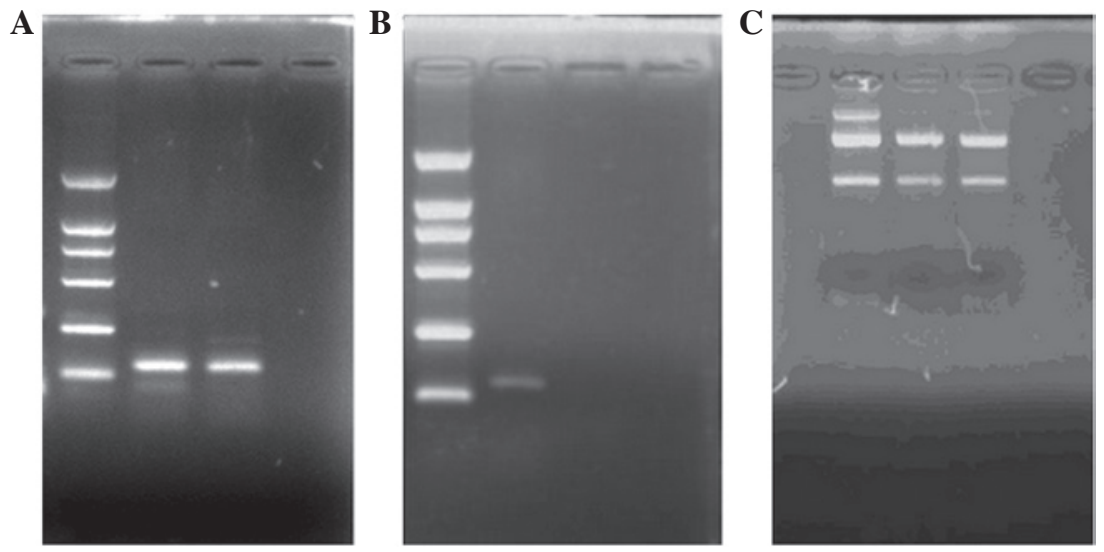

Figure 1. Agarose gel electrophoresis of qPCR amplification products. (A) Lane 1, DL2000 marker DNA (top to bottom: 2000, 1000, 750, 500, 240 and 100 bp); lane 2, $\beta$-actin (72 bp) and nociceptin/orphanin FQ peptide (NOP; 130 bp) mRNA; lane 3, NOP mRNA (130 bp). (B) Lane 1, DL2000 marker DNA; lane 2 , NOP mRNA (130 bp). (C) Total RNA of the three specimens; note the 28S and 18S rRNA bands.

mucosa $10 \mathrm{~cm}$ distal to the Treitz ligament were obtained from each subject who underwent enteroscopy and four specimens of colonic mucosa were obtained from the ascending colon $5 \mathrm{~cm}$ distal to the ileocecal valve of each subject who underwent colonoscopy.

Two jejunal mucosal and two colonic mucosal specimens from each subject were immediately frozen in liquid nitrogen $\left(-170^{\circ} \mathrm{C}\right)$ and stored in an ultra-low refrigerator $\left(-80^{\circ} \mathrm{C}\right)$. The remaining samples were fixed in $10 \%$ neutral formaldehyde solution and embedded in paraffin wax.

RNA extraction. Total RNA was extracted from frozen specimens using TRIzol reagent (Invitrogen Life Technologies, Carlsbad, CA, USA) according to the manufacturer's instructions and quantified by measurement of absorbance at $260 \mathrm{~nm}$. RNA samples were evaluated using agarose gel electrophoresis, with the presence of $28 \mathrm{~S}$ and $18 \mathrm{~S}$ ribosomal RNA bands indicating the integrity of the samples (Fig. 1).

Quantitative PCR ( $q P C R)$. Following c-DNA synthesis, the expression of NOP receptor mRNA was assayed by amplification using the following primers: 5'-CTC GGC TGG TGC TGG TGG TA-3' (forward) and 5'-CGT GCA GAA GCG CAG AAT GG-3' (reverse). The expression was normalized relative to the expression of $\beta$-actin mRNA, which was amplified using the following primers: 5'-GGG TGT GAA CCA TGA GAA GTA TG-3' (forward) and 5'-CCA TCAC GCC ACA GTT TCC-3' (reverse). All primers were designed and synthesized by Sangon Biology Co. (Shanghai, China). Each $50 \mu \mathrm{l}$ reaction contained $25 \mu 12 X$ PCR Master Mix (Roche Diagnostics, Switzerland), $1 \mu \mathrm{l}$ each forward and reverse primer (final concentration, $0.2 \mu \mathrm{M}$ each), $1 \mu \mathrm{l}$ ROX (fluorescence base), $1 \mu 1$ cDNA and $21 \mu \mathrm{lddH_{2 }} \mathrm{O}$. The amplification protocol consisted of 1 cycle of denaturation at $95^{\circ} \mathrm{C}$ for 2 min and 40 cycles of denaturation at $94^{\circ} \mathrm{C}$ for $30 \mathrm{sec}$, annealing at $62^{\circ} \mathrm{C}$ for $30 \mathrm{sec}$ and extension at $72^{\circ} \mathrm{C}$ for $30 \mathrm{sec}$. The amplification products were assessed by electrophoresis in $1.6 \%$ agarose gels and staining in $0.5 \mu \mathrm{g} / \mathrm{ml}$ ethidium bromide.

Following each PCR amplification, the fluorescence intensity curve was generated automatically (Figs. 2 and 3). The fluorescence thresholds for $\beta$-actin and NOP receptor mRNA retrovirus product by the maximal curvature method were 44.2 and 56.4, respectively. The number of cycles at which the fluorescence signal reached the threshold was defined as the cycle threshold $(\mathrm{Ct})$ value. To calibrate differences between each specimen and the retrovirus products, the $\beta$-actin $\mathrm{Ct}$ was subtracted from the NOP $\mathrm{Ct}$ value for each specimen. Standardized values were analyzed using the $\Delta \Delta \mathrm{Ct}$ method to determine the relative amount of NOP receptor mRNA in each specimen.

Immunohistochemistry. Paraffin sections were dewaxed at room temperature using dimethylbenzene, twice for $15 \mathrm{~min}$ and then hydrated in an ethyl alcohol series (100, 95, 90, 80 and $70 \%$ ) for $6 \mathrm{~min}$. The samples were washed in 1X phosphate-buffered saline (PBS) for $35 \mathrm{~min}$ and the tissues were then blocked by incubation in $3 \% \mathrm{H}_{2} \mathrm{O}_{2}$ for $15 \mathrm{~min}$ at $37^{\circ} \mathrm{C}$. Then, the samples were washed three times for $1 \mathrm{~min}$ each in $1 \mathrm{X}$ PBS, incubated with goat serum for $15 \mathrm{~min}$ at $37^{\circ} \mathrm{C}$ and incubated with rabbit anti-nociceptin (1:200; Phoenix Pharmaceuticals, Inc., Burlingame, CA, USA) for 2-3 h at room temperature. The samples were washed three times for 5 min each with PBS and incubated with $50 \mu$ goat antirabbit IgG-horseradish peroxidase (HRP) for $40 \mathrm{~min}$ at $37^{\circ} \mathrm{C}$. Following three washes in PBS for 5 min each, the samples were incubated in HRP-labeled streptomycin-avidin working solution (S-A/HRP) for $30 \mathrm{~min}$ at $37^{\circ} \mathrm{C}$. Then, the samples were washed three times for 5 min each with PBS and the color was developed using 3,3'-diaminobenzidine (DAB) for 1-2 min. The sections were rinsed in running water, duplicated with hematin, rinsed again in running water and dehydrated with laddered density alcohol. The samples were made transparent by incubation in dimethybenzene for $10 \mathrm{~min}$, sealed with neutral tree glue and viewed by optical microscopy.

Statistical analysis. All data are expressed as the mean \pm standard error of the mean (SEM) and analyzed using the multi-independent sample Kruskal-Wallis H-test, with the Nemenyi test used to identify significant differences among the three groups. All statistical analyses were performed using SPSS 13.0 software (SPSS, Inc., Chicago, IL, USA). P<0.05 was considered to indicate a statistically significant difference. 
Table I. Demographic characteristics of the study subjects.

\begin{tabular}{lcccccccc}
\hline & \multicolumn{2}{c}{ Control } & & \multicolumn{2}{c}{ D-IBS } & & \multicolumn{2}{c}{ C-IBS } \\
\cline { 2 - 3 } & Jejunum & Colon & & Jejunum & Colon & & Jejunum & Colon \\
\hline Number of subjects & 9 & 11 & & 15 & 12 & & 10 & 13 \\
Gender (male/female) & $5 / 4$ & $5 / 6$ & & $9 / 6$ & $5 / 7$ & & $4 / 6$ & $7 / 6$ \\
Age range (mean, years) & $21-54(34.0)$ & $20-65(34.0)$ & & $24-60(36.0)$ & $25-63(37.2)$ & & $19-53(34.4)$ & $19-68(38.3)$ \\
Course of disease (months) & & & & $45.4 \pm 24.6$ & $52.8 \pm 29.3$ & & $89.7 \pm 62.8$ & $82.1 \pm 56.4$
\end{tabular}

D-IBS, diarrhea-predominant irritable bowel syndrome; C-IBS, constipation-predominant irritable bowel syndrome.

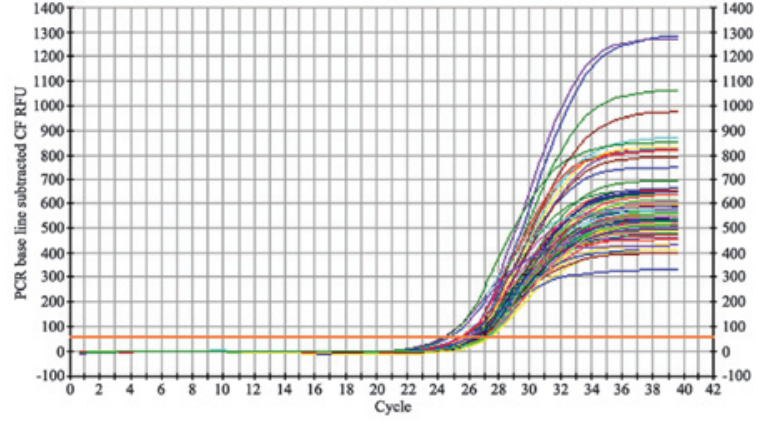

Figure 2. Fluorescence intensity curves for $\beta$-actin mRNA. PCR, polymerase chain reaction; $\mathrm{CF}$, curve fit; $\mathrm{RFU}$, relative fluorescence unit.

\section{Results}

Demographic data. We assessed 20 healthy subjects as the control group, 27 patients diagnosed with D-IBS and 23 patients diagnosed with C-IBS. All subjects underwent colonoscopy or double-balloon pushed enteroscopy to obtain specimens of the colon or jejunum (Table I).

Expression of NOP receptor $m R N A$. Using specific primers, we obtained a qPCR product for NOP mRNA of $~ 130 \mathrm{bp}$; the presence of $28 \mathrm{~S}$ and $18 \mathrm{~S}$ rRNA bands demonstrated that the total mRNA remained intact (Fig. 1). The fluorescence intensity curves for $\beta$-actin (Fig. 2) and the NOP receptor (Fig. 3) illustrate the quality of the mRNA samples.

Expression of NOP receptor $m R N A$ in the gut mucosa of healthy subjects. We observed that NOP receptor mRNA was expressed in all mucosal specimens from the control group, and the relative quantification was $7.86 \pm 4.66$ in jejunum specimens and $1.04 \pm 0.33$ in colon specimens respectively. This indicated that, the normalized level of expression was significantly higher in jejunum specimens than in colon specimens (Table II).

Expression of NOP receptor $m R N A$ in patients with IBS. The results showed that the relative expression of NOP receptor mRNA was $2.71 \pm 2.31$ in jejunum specimens and $0.32 \pm 0.11$ in colon specimens of D-IBS patients. These data were significantly lower than in samples from healthy controls. However, the relative expression of NOP receptor mRNA was $6.66 \pm 4.94$ in jejunum specimens and $1.05 \pm 1.26$ in colon specimens of

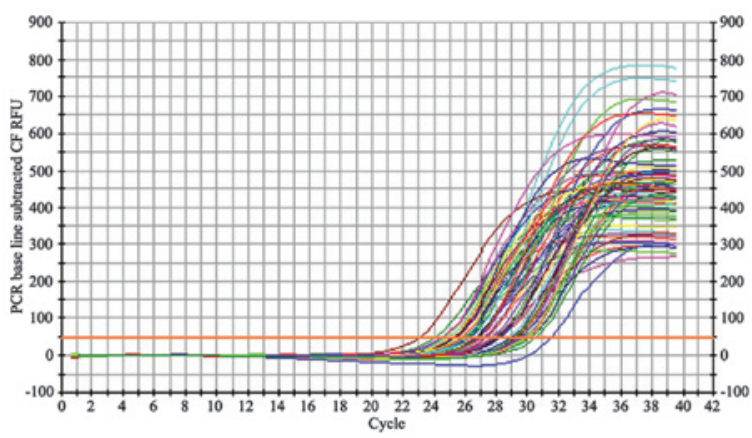

Figure 3. Fluorescence intensity curves for NOP receptor mRNA. PCR, polymerase chain reaction; $\mathrm{CF}$, curve fit; RFU, relative fluorescence unit; NOP, nociceptin/orphanin FQ peptide.

C-IBS patients, and no difference was observed between C-IBS and the control (Table II).

Immunohistochemistry. The OFQ-positive cells were stained dark brown in color following incubation with anti-nociceptin antibody (Fig. 4). We observed no differences in the number of OFQ-positive cells among the control, D-IBS and C-IBS groups, in the colonic or jejunal mucosa.

\section{Discussion}

The heptadecapeptide N/OFQ is the endogenous ligand for the NOP receptor and shares significant homology with classical opioid receptors $(15,16)$. The N/OFQ system is widely distributed throughout the CNS and in peripheral organs of various species $(15,17-21)$. Using $\mathrm{qPCR}$, the N/OFQ system has been detected in the alimentary tracts of rats, pigs and guinea pigs $(19,22)$. Using immunohistochemistry, N/OFQ has been shown to be localized in the rat enteric nervous system, with the mRNA encoding its precursor (prepro$\mathrm{OFQ} /-\mathrm{N}$ ) and the cognate receptor ORL-1 expressed in the intestinal tract. Similar to classical opioids $(23,24), \mathrm{N} / \mathrm{OFQ}$ has been shown to affect gastrointestinal motor and secretory responses, in vitro and in vivo. Unlike opioids, however, $\mathrm{N} / \mathrm{OFQ}$ is insensitive to naloxone (25-27). Although N/OFQ has been observed to inhibit neurogenic contractions of the stomach and small intestine in vitro, it has also been shown to contract the rodent colon. In vivo, N/OFQ acts at sites in the central and peripheral nervous systems stimulating mechanical activity in the stomach and inhibiting this activity 
Table II. Relative quantification of NOP receptor mRNA in control subjects and IBS patients.

\begin{tabular}{|c|c|c|c|c|c|c|}
\hline & \multicolumn{2}{|c|}{ Control } & \multicolumn{2}{|c|}{ D-IBS } & \multicolumn{2}{|c|}{ C-IBS } \\
\hline & Jejunum & Colon & Jejunum & Colon & Jejunum & Colon \\
\hline Number of subjects & 9 & 11 & 15 & 12 & 10 & 13 \\
\hline Relative quantification & $7.86 \pm 4.66$ & $1.04 \pm 0.33^{\mathrm{a}}$ & $2.71 \pm 2.31^{\mathrm{b}}$ & $0.32 \pm 0.11^{\mathrm{c}}$ & $6.66 \pm 4.94$ & $1.05 \pm 1.26$ \\
\hline
\end{tabular}
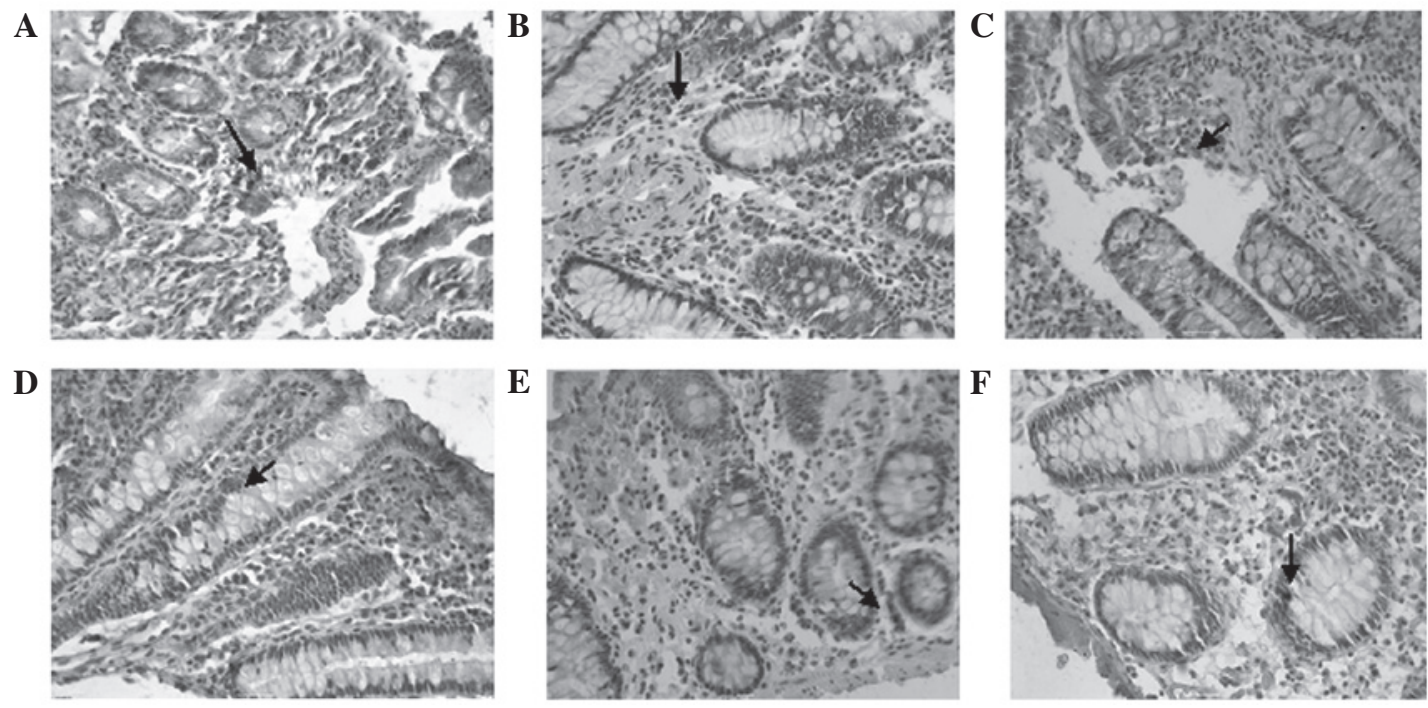

Figure 4. Anti-nociceptin antibody staining of jejunum specimens from the control (A), D-IBS (B) and C-IBS (C) groups, as well as staining of colon specimens from the control (D), D-IBS (E) and C-IBS (F) groups. Arrows indicate positive cells. D-IBS, diarrhea-predominant irritable bowel syndrome; C-IBS, constipation-predominant irritable bowel syndrome. Immuno-histochemical SABC staining; magnification, $\mathrm{x} 400$.

in the colon $(25,28)$. Thus, N/OFQ acts as a neuromodulator of gastrointestinal motility and may have additional roles in the regulation of intestinal blood flow, active ion transport and immunity (25). Furthermore, the distribution and level of expression of the N/OFQ system differs among different species, as does the mechanism of regulation and functional sites (22-25).

In the current study, we demonstrated that NOP receptor mRNA and protein were present in the mucosal cells of the jejunum and colon of healthy subjects and patients with IBS, suggesting that the N/OFQ system plays an important role in regulating the pathophysiological onset of intestinal function. qPCR demonstrated that the level of expression of NOP receptor mRNA was higher in the jejunum than in the colon in healthy subjects, suggesting that the regulation of gastrointestinal motion, secretion and immunity is more complex in the jejunum than in the colon $(29,30)$ and that the involvement of the NOP receptor in regulation is proportional to its level of expression.

Using immunohistochemical staining, we observed no differences in the number of OFQ-positive cells in the colonic or jejunal mucosa among the three groups of subjects, suggesting that OFQ may not be involved in the pathogenesis of IBS. These findings may also indicate, however, that the sensitivity of our immunohistochemical methods is insufficient to detect differences in protein expression $(31,32)$.

The etiopathogenesis of IBS remains unclear. Although the majority of patients with IBS also have psychiatric symptoms, causality has not been demonstrated. Thus, although antidepressants are effective in the treatment of these patients, IBS is considered a functional gastrointestinal disease (33). Moreover, the pathogenesis of IBS is closely related to disturbances in the brain-gut axis (34).

The level of NOP mRNA in the colon and jejunum was lower in patients with D-IBS than in healthy subjects, whereas no differences were observed between patients with C-IBS and healthy subjects. It is not clear, however, whether these differences between D-IBS and C-IBS patients are related to the pathophysiological mechanisms of these types of IBS, whether an imbalance in the N/OFQ system is partly responsible for the oversensitivity of the intestinal tract in IBS patients or whether NOP overexpression $(25,28)$ induces contraction of the human small intestine and colon in IBS patients.

In the central and peripheral nervous systems, the $\mathrm{N} / \mathrm{OFQ}$ system regulates the release and transit of neurotransmitters, including norepinephrine, dopamine, 5-hydroxytryptamine 
and $\gamma$-aminobutyric acid $(35,36)$. Our results suggest that the N/OFQ system also regulates the expression of neurotransmitters that act on intestinal motion and that the brain-gut axis is involved in these processes by an undetermined mechanism. Investigation of the N/OFQ system may be important in determining the pathogenesis of functional gastroenteropathies, including IBS.

\section{Acknowledgements}

This study was supported by the Hospital Innovation Funds of Xi'an Jiaotong University. The authors are grateful to Professor Jianli Wang for the assistance in statistical analyses and to Professor Jun Yang for technical assistance.

\section{References}

1. Neal KR, Hebden J and Spiller R: Prevalence of gastrointestinal symptoms six months after bacterial gastroenteritis and risk factors for development of the irritable bowel syndrome: postal survey of patients. BMJ 314: 779-782, 1997.

2. Drossman DA, Li Z, Andruzzi E, et al: U.S. householder survey of functional gastrointestinal disorders. Prevalence, sociodemography, and health impact. Dig Dis Sci 38: 1569-1580, 1993.

3. Dean BB, Aguilar D, Barghout V, et al: Impairment in work productivity and health-related quality of life in patients with IBS. Am J Manag Care 11 (Suppl 1): S17-S26, 2005.

4. El-Serag HB: Impact of irritable bowel syndrome: prevalence and effect on health-related quality of life. Rev Gastroenterol Disord 3 (Suppl 2): S3-S11, 2003.

5. El-Serag HB, Olden K and Bjorkman D: Health-related quality of life among persons with irritable bowel syndrome: a systematic review. Aliment Pharmacol Ther 16: 1171-1185, 2002.

6. Longstreth GF, Bolus R, Naliboff B, et al: Impact of irritable bowel syndrome on patients' lives: development and psychometric documentation of a disease-specific measure for use in clinical trials. Eur J Gastroenterol Hepatol 17: 411-420, 2005.

7. Hulisz D: The burden of illness of irritable bowel syndrome: current challenges and hope for the future. J Manag Care Pharm 10: 299-309, 2004.

8. Pace F, Molteni P, Bollani S, et al: Inflammatory bowel disease versus irritable bowel syndrome: a hospital-based, case-control study of disease impact on quality of life. Scand J Gastroentrol 38: 1031-1038, 2003

9. Kanazawa M, Palsson OS, Thiwan SI, et al: Contributions of pain sensitivity and colonic motility to IBS symptom severity and predominant bowel habits. Am J Gastroenterol 103: 2550-2561, 2008.

10. Olszewski PK, Grace MK, Fard SS, et al: Central nociceptin/orphanin FQ system elevates food consumption by both increasing energy intake and reducing aversive responsiveness. Am J Physiol Regul Integr Comp Physiol 299: R655-R663, 2010.

11. Przydzial MJ and Heisler LK: Nociceptin/orphanin FQ peptide receptor as a therapeutic target for obesity. Mini Rev Med Chem 8: 796-811, 2008.

12. Matsushita $\mathrm{H}$, Ishihara $\mathrm{A}$, Mashiko $\mathrm{S}$, et al: Chronic intracerebroventricular infusion of nociceptin/orphanin FQ produces body weight gain by affecting both feeding and energy metabolism in mice. Endocrinology 150: 2668-2673, 2009.

13. Agostini S, Eutamene H, Broccardo M, et al: Peripheral anti-nociceptive effect of nociceptin/orphanin FQ in inflammation and stress-induced colonic hyperalgesia in rats. Pain 141 292-299, 2009.

14. Drossman DA and Dumitrascu DL: Rome III: New standard for functional gastrointestinal disorders. J Gastrointestin Liver Dis 15: 237-241, 2006.

15. Bunzow JR, Saez C, Mortrud M, et al: Molecular cloning and tissue distribution of a putative member of the rat opioid receptor gene family that is not a mu, delta or kappa opioid receptor type. FEBS Lett 347: 284-288, 1994.
16. Mogil JS and Pasternak GW: The molecular and behavioral pharmacology of the orphanin $\mathrm{FQ}$ /nociceptin peptide and receptor family. Pharmacol Rev 53: 381-415, 2001.

17. Anton B, Fein J, To T, Li X, Silberstein L and Evans CJ: Immunohistochemical localization of ORL-1 in the central nervous system of the rat. J Comp Neurol 368: 229-251, 1996.

18. Florin S, Leroux-Nicollet I, Meunier JC and Costentin J: Autoradiographic localization of $\left[{ }^{3} \mathrm{H}\right]$ nociceptin binding sites from telencephalic to mesencephalic regions of the mouse brain Neurosci Lett 230: 33-36, 1997.

19. Wang JB, Johnson PS, Imai Y, et al: cDNA cloning of an orphan opiate receptor gene family member and its splice variant. FEBS Lett 348: 75-79, 1994.

20. Nothacker HP, Reinscheid RK, Mansour A, et al: Primary structure and tissue distribution of the orphanin FQ precursor. Proc Natl Acad Sci USA 93: 8677-8682, 1996.

21. Mollereau C, Simons MJ, Soularue P, et al: Structure, tissue distribution, and chromosomal localization of the prepronociceptin gene. Proc Natl Acad Sci USA 93: 8666-8670, 1996.

22. Calo' G, Guerrini R, Rizzi A, Salvadori S and Regoli D: Pharmacology of nociceptin and its receptor: a novel therapeutic target. Br J Pharmacol 129: 1261-1283, 2000.

23. Fox DA and Burks TF: Roles of central and peripheral mu, delta and kappa receptors in the mediation of gastric acid secretory effects in the rat. J Pharmacol Exp Ther 244: 456-462, 1988.

24. Improta $\mathrm{G}$ and Broccardo M: Effect of selective mu 1, mu 2 and delta 2 opioid receptor agonists on gastric functions in the rat. Neuropharmacology 33: 977-981, 1994.

25. Osinski MA and Brown DR: Orphanin FQ/nociceptin: a novel neuromodulator of gastrointestinal function. Peptides 21: 999-1005, 2000.

26. Li HY, Yan X, Xue QL, et al: Effects of nociceptin/orphanin FQ on rats with cathartic colon. World J Gastroenterol 13: 141-145, 2007.

27. Broccardo M, Guerrini R, Petrella $C$ and Improta G: Gastrointestinal effects of intracerebroventricularly injected nociceptin/orphaninFQ in rats. Peptides 25: 1013-1020, 2004.

28. Takahashi T, Mizuta Y and Owyang C: Orphanin FQ, but not dynorphin A, accelerates colonic transit in rats. Gastroenterology 119: 71-79, 2000.

29. Kunkel EJ, Campbell JJ, Haraldsen G, et al: Lymphocyte CC chemokine receptor 9 and epithelial thymus-expressed chemokine (TECK) expression distinguish the small intestinal immune compartment: Epithelial expression of tissue-specific chemokines as an organizing principle in regional immunity. J Exp Med 192: 761-768, 2000.

30. Alemayehu A, Lock KR, Coatney RW and Chou CC: L-NAME, nitric oxide and jejunal motility, blood flow and oxygen uptake in dogs. Br J Pharmacol 111: 205-212, 1994.

31. Kamel HM, Willmott N, McNicol AM and Toner PG: The use of electron microscopy and immunocytochemistry to characterise spontaneously-arising, transplantable rat tumors. Virchows Arch B Cell Pathol Incl Mol Pathol 57: 11-18, 1989.

32. Looi LM, Yap SF and Cheah PL: Correlation between oestrogen receptor protein expression in infiltrating ductal carcinoma of the breast by immunohistochemistry and cytosol measurements. Ann Acad Med Singap 26: 750-753, 1997.

33. Ford AC, Talley NJ, Schoenfeld PS, Quigley EM and Moayyedi P: Efficacy of antidepressants and psychological therapies in irritable bowel syndrome: systematic review and meta-analysis. Gut 58: 367-378, 2009.

34. Ohman L and Simrén M: Pathogenesis of IBS: role of inflammation, immunity and neuroimmune interactions. Nat Rev Gastroenterol Hepatol 7: 163-173, 2010.

35. Lü N, Han M, Yang ZL, Wang YQ, Wu GC and Zhang YQ: Nociceptin/orphanin FQ in PAG modulates the release of amino acids, serotonin and norepinephrine in the rostral ventromedial medulla and spinal cord in rats. Pain 148: 414-425, 2010.

36. Yazdani A, Takahashi T, Bagnol D, Watson SJ and Owyang C: Functional significance of a newly discovered neuropeptide, orphanin FQ, in rat gastrointestinal motility. Gastroenterology 116: 108-117, 1999. 